\title{
Akut infantil hemorajik ödemli bir olgu
}

\section{A case of acute infantile hemorrhagic edema}

\author{
Samet Benli \\ Mehmet Tekin (D) \\ Adıyaman Üniversitesi Tıp Fakültesi, Çocuk Sağlığı ve Hastalıkları Anabilim Dalı, Adıyaman, Türkiye
}

\section{Öz}

Akut infantil hemorajik ödem (AïHÖ) genellikle 6-24 ay arasında görülen ve deriye sınırlı olan bir lökositoklastik vaskülit tablosudur. Hastalar ödem, ateş ve purpurik döküntü ile başvurmaktadır. Yaklaşık 2-4 hafta kadar sürede kendiliğinden iyileşmesine rağmen, döküntüler aileleri ciddi anlamda tedirgin edebilmektedir. Bu olguda üst solunum yolu enfeksiyonu sonrası purpura, ellerde ve ayaklarda şişme yakınmaları ile tarafımıza başvuran ve AïHÖ tanısı alan dokuz aylık bir çocuk sunuldu. Acil tıp, çocuk sağlığı ve hastalıkları ve cildiye uzmanlarının nadir görülen AïHÖ'yü tanımaları ve selim seyri konusunda hasta yakınlarını bilgilendirmelerinin, gereksiz araştırmaları ve ailelerin kaygılarını azaltacağını vurgulamak istedik.

Anahtar Sözcükler: Akut infantil hemorajik ödem, lökositoklastik vaskülit, purpura.

\begin{abstract}
Acute infantile hemorrhagic edema (AIHE) is a leukocytoclastic vasculitis limited to the skin and is usually seen between 6-24 months. Patients present with edema, fever and purpuric rash. Although the patients recover spontaneously in about 2-4 weeks, the rashes can seriously disturb their families. In this case, we presented a ninemonths-old child diagnosed with AHIE who was admitted to the hospital with purpura and swelling of hands and feet after an upper respiratory tract infection. We wanted to emphasize that recognition of the rare AlHE by emergency specialist, pediatricians, and dermatologists and informing the patient relatives about the benign course, will reduce unnecessary research and concerns of the families.
\end{abstract}

Keywords: Acute infantile hemorrhagic edema, leukocytoclastic vasculitis, purpura.

\section{Giriş}

Akut infantil hemorajik ödem (AïHÖ), lökositoklastik vaskülitin nadir bir türüdür. Genellikle iki yaş altında görülen, selim seyirli ve deriye sınırlı bir tablodur. Klinik triad olarak ödem, ateş ve purpurik deri lezyonları görülür (1). Döküntüler yüz, kalça, kulak ve ekstremitelerde simetrik yerleşimlidir ve anüler ya da hedef tarzındadır. Hastalığın ayırıcı tanısında HenochSchönlein purpurası (HSP), purpura fulminans, septisemi ve meningokoksemi gibi purpurik döküntülü hastalıklar düşünülmelidir (1). Bu olguda, üst solunum yolu enfeksiyonu sonrası gelişen AïHÖ tablosu sunuldu.

\footnotetext{
Yazışma Adresi: Mehmet Tekin

Adıyaman Üniversitesi Tıp Fakültesi, Çocuk Sağlığı ve Hastalıkları Anabilim Dalı, Adıyaman, Türkiye

E-posta:drmehmettekin@hotmail.com

Makalenin Geliş Tarihi:06.11.2017 Kabul Tarihi: 02.01.2018
}

\section{Olgu Sunumu}

Üç gün önce ateş ve burun akıntısı başlayan 9 aylık erkek hasta, bir gün önce de yüzünde ve ekstremitelerinde döküntüler oluşması üzerine Adıyaman Üniversitesi Tıp Fakültesi çocuk acil servisine başvurdu. Hastanın herhangi bir ilaç kullanım öyküsü yoktu. Özgeçmiş ve soy geçmişinde özellik yoktu. Fizik muayenesinde vücut Isısı $37,9^{\circ} \mathrm{C}$ ve orofarenksi hiperemikti. Yanaklarda, kulak kepçesinde, bacaklarda ve ayaklarda boyutları $4 \times 5 \mathrm{~cm}$ ile $2 \times 2 \mathrm{~cm}$ arasında değişen purpurik döküntüler mevcuttu (Şekil-1). Bacaklarda bilateral ödem saptandı. Hastanın vücut ağırlığı 8,4 kg (25-50 persentil) ve boyu $70 \mathrm{~cm}$ (25-50 persentil) idi. Laboratuvar incelemelerinde kan lökosit sayısı $14.600 / \mathrm{mm}^{3}$, trombosit sayısı $265.000 / \mathrm{mm}^{3}$, hemoglobin $9,1 \mathrm{~g} / \mathrm{dL}$ ve C-reaktif protein (CRP) 1.2 $\mathrm{mg} / \mathrm{dL}$ idi. Kan biyokimyası, tam idrar incelemesi, protrombin zamanı (PT) ve aktive parsiyel tromboplastin zamanı (aPTT) normal olarak saptandı. Gaitada gizli kan negatifti. Hastaneye yatışı sırasında alınan kan kültüründe üreme olmadı. Hastanın yaşı, selim seyreden kliniği, mukoza ve iç organlarda tutulum olmaması ve 
laboratuvar bulguları göz önüne alınarak AiHÖ tanısı kondu. Hastanın mevcut üst solunum yolu enfeksiyonu için ampisilin-sulbaktam $200 \mathrm{mg} / \mathrm{kg} / \mathrm{gün}$ başlandı ve serviste takibe alındı. Hasta yatışının üçüncü gününde taburcu edildi. Bir hafta sonraki kontrolde döküntülerin pigmentasyon bırakarak gerilediği gözlendi. Hastanın bir ay sonraki kontrolünde ise döküntülerin tamamen kaybolduğu görüldü.

Hastanın yasal vasisinden tıbbi verilerinin yayınlanabileceğine ilişkin yazılı onam belgesi alındı.

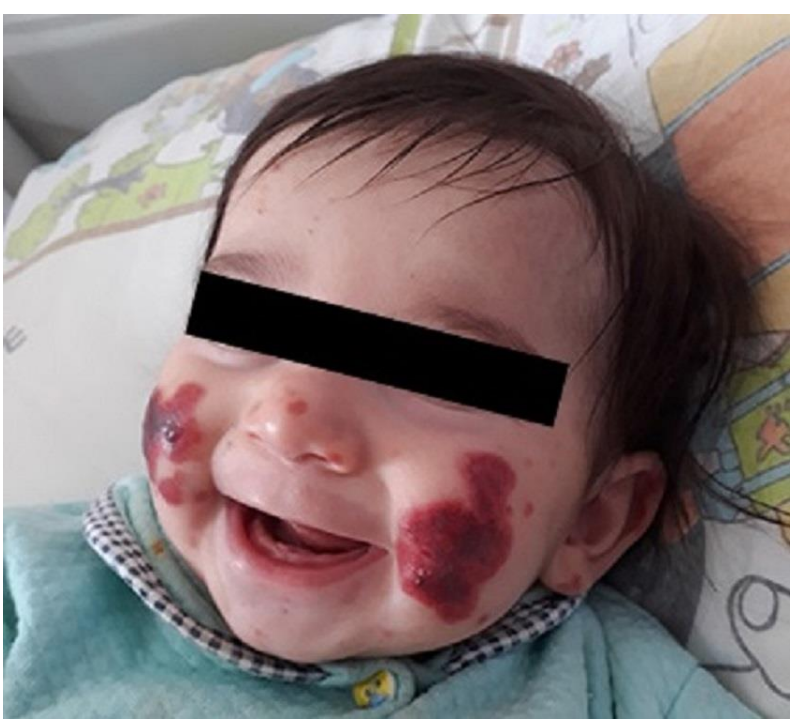

Şekil-1. Yüzde madalyon tarzında purpura.

\section{Tartışma}

Akut infantil hemorajik ödem ilk olarak Snow tarafından tanımlanmış, daha sonra Seidlmayer sendromu, Finkelstein hastalığı gibi isimlerle de anılmıştır (2). Lökositoklastik vaskülitin bir alt tipi olarak kabul edilir, nedeni kesin olarak bilinmemektedir. Olguların çoğundan enfeksiyonların, ilaçların ve immünizasyonun sorumlu olduğu bildirilmektedir. Enfeksiyon etkeni olarak en sık stafilakoklar, streptokoklar ve adenovirüsler saptanmıştır (3). Olgumuzun kan kültüründe üreme olmadı. İlaçlardan non-steroid antiinflamatuvarlar, trimetoprim sülfametaksazol ve penisilin grubu antibiyotikler sorumlu tutulmuştur (4). Olgumuzda ilaç kullanma öyküsü yoktu, bu nedenle döküntülerin enfeksiyöz kaynaklı olduğu düşünüldü.
AlHÖ, kendi kendini sınırlayan ve yaklaşık 1-3 hafta kadar sürede düzelen bir tablodur. Hastalığın erkek çocuklarda daha sık gözlendiği bildirilmiştir (5). Literatürle uyumlu olarak olgumuz da erkekti. Hastalık purpura tarzındaki döküntülerin yüz, kulak kepçesi ve ekstremitelere yayılması ile kendini gösterir. Döküntüler ödemli ve birleşme eğilimindedir. Deri bulguları progresif seyir göstermesine rağmen, hastalık iyi huyludur ve yaklaşık 1-3 hafta içerisinde kendiliğinden gerilemektedir (3). Olgumuzda da klinik hafif seyretti ve döküntüler bir ay sonra tamamen kayboldu.

AlHÖ ayırıcı tanısında HSP, meningokoksemi, purpura fulminans, Kawasaki hastalığı ve eritema multiforme düşünülmelidir (1). Çocukluk çağında en sık görülen lökositoklastik vaskülit türü HSP'dir. AlHÖ ile HSP benzer hastalıklar olmakla birlikte, aralarında bazı klinik ve laboratuvar farklılıklar vardır. AïÖ sıklıkla 4-24 aylar arasında görülürken, HSP genelde üç yaş sonrası gözlenir. Palpabl purpura tarzındaki döküntüler HSP'de genelde bacaklarda ve gluteal bölgede yerleşimli iken; AïHÖ'de özellikle yüz, kulak kepçesi ve ekstremite distalindedir ve daha geniş, ödemin eşlik ettiği ve birleşme eğiliminde olan madalyon şeklindedir (6). Olgumuzda da özellikle her iki yanakta, kulak kepçesinde ve ayaklarda birleşme eğiliminde olan madalyon tarzında purpurik döküntüler mevcuttu. Tetkiklerinde hafif lökositoz ve CRP pozitifliği vardı. Böbrek tutulumu ve gastrointestinal tutulum saptanmadı.

Hastalığın özgün bir tedavisi yoktur. Altta yatan hastalık varsa ona yönelik tedavi yapılmalıdır. Sistemik steroid ve antihistaminiklerin kullanımı tartışmalı olup, steroid tedavisinden 24 saat sonra lezyonların hızla gerilediğini gösteren çalışmalar bulunmaktadır $(7,8)$. Olgumuzda steroid kullanılmadı.

Akut infantil hemorajik ödem, büyük purpurik döküntüleri nedeniyle ailelerde endişe uyandırabilmektedir. Bu olgu sunumunda özellikle acil, pediatri ve cildiye doktorlarının nadir görülen AïHÖ tablosunu tanımaları ve selim seyri konusunda hasta yakınlarını bilgilendirmelerinin, gereksiz araştırmaları ve ailelerin kaygılarını azaltacağını vurgulamak istedik.

\section{Kaynaklar}

1. Homme JL, Block JM. Acute hemorrhagic edema of infancy and common mimics. Am J Emerg Med 2016:34(5):936.

2. Çakçak DS, Çakçak B, Akman A, Güney SV, Başsorgun Ci, Çiftçioğlu MA. Purpuranın ayırıcı tanısında yer alan akut infantil hemorajik ödem olgusu. Türk Dermatoloji Dergisi 2008;2:84-6.

3. Fiore E, Rizzi M, Simonetti GD, Garzoni L, Bianchetti MG, Bettinelli A. Acute hemorrhagic edema of young children: a concise narrative review. Eur J Pediatr 2011;170(12):1507-11.

4. Küçüktaşcı K, Semiz S, Çolpan A. Akut infantil hemorajik ödem. Türkiye Çocuk Hast Derg 2010;4(2):109-13.

5. Fiore E, Rizzi M, Ragazzi M, et al. Acute hemorrhagic edema of young children (cockade purpura and edema): a case series and systematic review. J Am Acad Dermatol 2008;59(4):684-95.

6. Sert A, Yazar A, Odabaş D, Çelik AY. Akut İnfantil Hemorajik Ödem; İki Olgu Sunumu. Van Tıp Dergisi 2013;20(3):162-65.

7. Offidani A, Cellini A, Bossi G. Guess what! Acute haemorrhagic oedema of the skin in infancy. Eur J Dermatol 2001;11(1):63-4.

8. da Silva Manzoni AP, Viecili JB, de Andrade CB, Kruse RL, Bakos L, Cestari TF. Acute hemorrhagic edema of infancy: a case report. Int J Dermatol 2004;43:48-51. 